\title{
Impementasi Pembelajaran Fisika Pokok Bahasan Elastisitas Melalui Inquiry Based Learning di SMA Negeri 2 Donggo
}

\author{
Soekarman \\ SMA Negeri 2 Donggo, Kabupaten Bima - Provinsi NTB \\ Corresponding Author. Email: Soekarmanman1981@gmail.com
}

\begin{abstract}
The purpose of this study was to describe the feasibility of the inquiry learning process of elasticity material using the P4TK IPA Hooke Law learning unit in class XI IPA students at SMA Negeri 2 Donggo. In the learning process of the elasticity material using Hooke's Law learning unit with an inquiry learning model with 6 levels. This research method used descriptive method. The research instrument used observation, interview, and tests. The data analysis technique used quantitative descriptive analysis. The results of this study indicate that the inquiry learning process on the subject of Elasticity and Hooke's Law using the Hooke P4TK IPA Law Physics learning unit in class XI IPA students of SMA Negeri 2 Donggo can be implemented properly and student learning outcomes are $100 \%$ complete.
\end{abstract}

\section{Article History}

Received: 17-02-2021

Revised: 11-03-2021

Published: 04-04-2021

\section{Key Words:}

Learning, Inquiry, Physics.

\begin{abstract}
Abstrak: Tujuan penelitian ini adalah untuk mendeskripsikan keterlaksanaan Sejarah Artikel proses pembelajaran inkuiri materi elastisitas dengan menggunakan unit Diterima: 17-02-2021 pembelajaran Hukum Hooke P4TK IPA pada siswa kelas XI IPA di SMA Direvisi: 11-03-2021 Negeri 2 Donggo. Dalam proses pembelajaran materi Elastisitas menggunakan Diterbitkan: 04-04-2021 Unit pembelajaran Hukum Hooke dengan model pembelajaran inkuiri dengan 6 level. Metode penelitian ini menggunakan metode deskriptif. Instrumen penelitiannya menggunakan observasi, wawancara, dan tes. Teknik analisis datanya menggunakan analisis deskriptif kuantitatif. Hasil penelitian ini Kata Kunci: menunjukkan bahwa proses pembelajaran inkuiri pada materi Elastisitas dan Pembelajaran, Inkuiri, Hukum Hooke dengan menggunakan unit pembelajaran Fisika Hukum Hooke Fisika. P4TK IPA pada siswa kelas XI IPA SMA Negeri 2 Donggo dapat dilaksanakan dengan baik dan hasil belajar siswa $100 \%$ tuntas.
\end{abstract}

How to Cite: Soekarman, S. (2021). Impementasi Pembelajaran Fisika Pokok Bahasan Elastisitas Melalui Inquiry Based Learning di SMA Negeri 2 Donggo. Jurnal Paedagogy, 8(2). doi:https://doi.org/10.33394/jp.v8i2.3521

https://doi.org/10.33394/jp.v8i2.3521

This is an open-access article under the CC-BY-SA License.

\section{Pendahuluan}

Sains atau Fisika merupakan cara mencari tahu tentang alam secara sistematis untuk menguasai pengetahuan, fakta, konsep, prinsip, proses penemuan dan memiliki sikap ilmiah. Sains juga dapat diartikan sebagai mengamati apa yang terjadi, memahami apa yang diamati, menggunakan pengetahuan baru untuk meramalkan apa yang akan terjadi, dan menguji ramalan dibawah kondisi tertentu untuk melihat apakah ramalan tersebut benar.

Sebagai mata pelajaran, sains memuat dua aspek yang tidak terpisahkan, yaitu yang kita kenal sebagai produk dan proses. Sebagai produk, sains merupakan seperangkat pengetahuan yang terangkai menjadi suatu badan pengetahuan (body of knowledge) yang telah dibangun para ilmuwan dalam rangka menjelaskan fenomena alam sehari-hari, baik yang terjadi secara alami maupun yang terjadi atas campur tangan atau rekayasa manusia. Di pihak lain, sebagai proses, sains merupakan seperangkat praktik (amalan) yang biasa dilakukan para ilmuwan untuk merumuskan baru, menyempurnakan pengetahuan yang sudah dibangun, dan merangkai pengetahuan-pengetahuan yang telah dirumuskan menjadi badan 
pengetahuan yang semakin koheren dan lengkap. Implikasi dari pandangan tersebut adalah bahwa pelajaran sains di sekolah tidak cukup hanya untuk membantu siswa menguasai pengetahuan sains semata, melainkan juga untuk memfasilitasi siswa mengalami sendiri membangun pengetahuan sains melalui serangkaian proses seperti yang dilakukan para ilmuwan.

Produk-produk sains yang perlu dikuasai siswa sudah terumuskan dengan cukup baik dalam berbagai buku ajar, atau dalam standar isi kurikulum sains. Di pihak lain, proses sains belum berhasil dirumuskan secara komprehensif sehingga bisa disepakati oleh para pemangku kepentingan pendidikan sains. Sebagaimana telah disebutkan, proses sains merupakan seperangkat praktik (amalan) yang biasa dilakukan para ilmuwan dalam mengembangkan body of knowledge sains. Meskipun sepintas cukup jelas, ungkapan tersebut sesungguhnya sulit dioperasionalkan mengingat tidak ada satu pun rangkaian proses atau metode ilmiah tertentu yang disepakati dan harus ditaati ilmuwan dalam mengembangkan pengetahuan sains.

Sejarah perkembangan sains juga menunjukkan bahwa lompatan-lompatan besar dalam perkembangan sains seringkali tidak lahir dari penerapan "metode ilmiah" tersebut. Gagasan sesaat (momentarily insight) untuk memecahkan kebuntuan, intuisi, dan keberuntungan (luck) juga memainkan peran penting dalam perkembangan sains. Sebagai contoh, gagasan sesaat Einstein yang mempostulatkan bahwa laju cahaya sama untuk semua pengamat lahir dari kebuntuan upaya ilmuwan saat itu dalam menentukan kerangka acuan yang harus digunakan untuk menentukan kecepatan cahaya di ruang hampa, yang oleh Maxwell diprediksikan sebesar 300 juta meter per sekon (saat itu diusulkan zat hipotetik yang dinamai ether, namun tidak ada eksperimen yang berhasil mebuktikan keberadaannya). Seperti yang kita ketahui, ide cemerlang Einstein tersebut telah melahirkan teori relativitas khusus, yang merupakan salah satu pilar fisika modern. Lahirnya fisika kuantum, pilar lain fisika modern, juga berkat gagasan sesaat Einstein untuk menggabungkan dua sifat yang dimiliki cahaya, yaitu sebagai partikel (foton) dan gelombang; dua sifat yang saat itu dipikirkan tidak mungkin dapat dimiliki sekaligus oleh suatu entitas fisik. Saat itu terjadi perdebatan di kalangan ilmuwan tentang hakekat cahaya: sebagai partikel atau kah sebagai gelombang. Mengingat dua watak itu sama-sama ditunjukkan oleh cahaya, meskipun dalam konteks yang berbeda, maka Einstein mengusulkan agar kedua watak tersebut dipikirkan untuk dimiliki sekaligus oleh cahaya. Pemikiran Einstein tersebut memicu intuisi de Broglie untuk mengusulkan sebaliknya: kalau cahaya yang semula diyakini sebagai gelombang ternyata juga dapat berwatak sebagai partikel, maka objek-objek fisik yang selama ini kita kenali sebagai partikel (misalnya electron) seharusnya juga bisa berwatak sebagai gelombang jika situasinya memungkinkan. Terobosan berpikir Einstein dan de Broglie tersebut telah menghantarkan lahirnya fisika kuantum sekaligus menandai era baru perkembangan fisika yang dalam sejarah sains dikenal sebagai era fisika modern.

Dalam rangka menerapkan pembelajaran yang inovatif, SMA Negeri 2 Donggo Kabupaten Bima merupakan salah satu Sekolah yang telah menerapkan strategi pembelajaran dengan pendekatan Inkuiri di Bidang Fisika. Pembelajaran berbasis inkuiri merupakan kegiatan pembelajaran yang melibatkan secara maksimal seluruh kemampuan siswa untuk mencari dan menyelidiki sesuatu fenomena alam, makhluk hidup atau benda, secara sistematis kritis, analitis dan logis (Anisa, 2020; Nahak, 2020; Nurkhasanah, 2019; dan Seprianingsih, 2017). Dalam pelaksanaannya dituntut untuk melakukan perubahan dalam menerapkan pendekatan pembelajaran yang berpusat pada guru (teacher centered 
learning) menjadi pendekatan pembelajaran yang berpusat pada siswa (student-centered learning). Hal ini disesuaikan dengan tuntutan pembelajaran yang akan mempengaruhi perkembangan anak di masa depan, dimana anak harus memiliki kecakapan berpikir dan belajar (thinking and learning skils). Kecakapan-kecakapan tersebut diantaranya adalah kecakapan berpikir kritis (critical thinking), memecahkan masalah (problem solving), kolaborasi, dan kecakapan berkomunikasi yang sering dikatakan sebagai Kecakapan Abad 21. Siswa dapat memiliki kecakapan- kecakapan itu apabila guru mampu mengembangkan pembelajaran dengan aktivitas kegiatan-kegiatan yang menantang siswa untuk berpikir kritis dalam memecahkan masalah. Namun demikian sampai saat ini masih terjadi kesenjangan antara apa yang diajarkan di kelas dengan apa yang terjadi dalam lingkungan sekitarnya. Di samping itu pelajaran Fisika masih dianggap pelajaran yang paling sulit, sehingga anggapan tersebut melekat diingatan siswa yang pada akhirnya siswa tidak tertarik dalam mengikuti pelajaran.

Hasil Ujian Nasional Fisika dari tahun-ketahun masih memiliki rata-rata yang rendah di bandingkan dengan mata pelajaran lain. Begitu pula nilai Fisika di tingkat satuan pendidikan untuk setiap kali ulangan harian siswa yang tuntas belajar hanya sekitar $50 \%$ dengan $\mathrm{KKM}=70$. Hal ini disebabkan karena dalam kegiatan belajar mengajar siswa kurang diberikan kegiatan-kegiatan yang dapat merangsang keaktifan belajar, keingintahuan dan ingin mencoba dan membuktikan apa yang dia pelajari. Siswa hanya mampu menguasai soal-soal yang bersifat ingatan dari 6 level kognitif yang ada baru dikuasai level C-1 dan C-2 sementara jika soal mulai dari penerapan (level C-3) ke atas mulai mengalami kesulitan. Hal ini disebabkan: pertama sudah terbiasa soal-soal yang diberikan oleh guru hanya berisi level-level rendah saja, yang kedua saat pembelajaran di kelas kurang diberikan kegitankegiatan yang menantang untuk berpikir pada level yang lebih tinggi.

Oleh karena itu, dalam penelitian ini diterapkan pembelajaran berbasis inkuiri untuk mengatasi masalah tersebut dalam memenuhi tututan Kurikulum Nasional 2013 dan Kecakapan abad 21, pada proses pembelajaran Fisika materi Elastisitas di kelas XI IPA SMA Negeri 2 Donggo Kabupaten Bima.

\section{Metode Penelitian}

Metode penelitian ini menggunakan penelitian deskriptif. Subyek penelitian adalah siswa kelas XI IPA SMA Negeri 2 Donggo, Kab. Bima Provinsi Nusa Tenggara Barat berjumlah 36 orang. Kelas ini dipilih karena kemampuan Akademik terus menurun dan untuk kelas XI IPA hanya satu Rombel saja. Penelitian dilakukan dengan 3 kali pertemuan masing masing 4 jam pelajaran dalam satu pekan (1 JP @ 45 menit) semester ganjil tahun pelajaran 2019/2020. Instrumen penelitian ini menggunakan observasi, wawancara, dan tes. Untuk mengetahuai peningkatan hasil belajar aspek pengetahuan di gunakan teknik analisis data secara kuantitatif. Analisis yang digunakan dalam penelitian ini adalah analisis deskriptif, yang digunakan untuk menggambarkan hasil belajar siswa. Kemudian data hasil tes siswa dianalisis dengan statistik. Kriteria Ketuntasan Minimal (KKM) pelajaran fisika kelas XI materi Hukum Hooke di SMA Negeri 2 Donggo adalah 70. Sedangkan untuk mengetahui peningkatan hasil belajar aspek keterampilan /keaktifan siswa di gunakan lembar observasi. Perhitungan data lembar observasi dilakukan dengan menhitung jumlah siswa yang aktif dari setiap siklus dengan menghitung banyaknya kemunculan tanda $(\sqrt{ })$. Untuk tanggapan siswa terhadap penerapan pembelajaran berbasis inkuri dilakukan dengan wawamcara kepada siswa setelah pembelajaran selesain dilaksakan. 


\section{Hasil Penelitian dan Pembahasan}

Pembelajaran di sekolah dapat dilakukan dengan pendekatan inkuiri maupun pemecahan masalah (problem solving). Model inkuiri merupakan salah satu model pembelajaran kognitif yang diunggulkan untuk pembelajaran sains di sekolah (Joyce, et al., 2000). Dalam pembalajaran inkuiri belajar dilakukan dalam kelompok kecil, agar dapat menumbuhkan pengetahuan, kemampuan berpikir, sikap dan keterampilan komunikasi. Menurut Wenning (2011) model inkuiri terdiri dari tahap-tahap berikut: discovery learning, interactive demonstrations, inquiry lessons, inquiry labs, and hypothetical inquiry (disebut juga inquiry spectrum). guru akan membantu peserta didik mengembangkan yang lebih luas. Berbagai keterampilan proses intelektual dan ilmiah. Sekarang termasuk dalam spectrum inkuiri adalah aplikasi dunia nyata dengan dua variannya memecahkan masalah di akhir bab dan memecahkan masalah yang autentik. Proses pembelajaran pada setiap level of inquiry diuraikan pada tabel berikut:

\section{Tabel 1: Level of Inquiry}

\begin{tabular}{|c|c|}
\hline $\begin{array}{l}\text { Discovery Learning (DL): } \\
\text { Peserta didik diberi beberapa jenis pegas } \\
\text { untuk diamati, guru mengarahkan perhatian } \\
\text { dan tindakan siswa pada konsep-konsep } \\
\text { berikut: tetapan pegas, gaya luar, pertambahan } \\
\text { panjang, dan gaya pulih }\end{array}$ & $\begin{array}{l}\text { Interactive Demonstrations (ID): } \\
\text { Guru menunjukkan pengaruh perubahan gaya } \\
\text { terhadap pertambahan panjang pegas. Peserta } \\
\text { didik difokuskan untuk dapat memprediksi } \\
\text { hubungan antara gaya luar, gaya pulih dan } \\
\text { pertambahan panjang pegas. }\end{array}$ \\
\hline $\begin{array}{l}\text { Inquiry Lessons: } \\
\text { Peserta didik melakukan percobaan untuk } \\
\text { mengamati hubungan antara massa beban } \\
\text { dengan pertambahan panjang pegas melalui } \\
\text { pengumpulan data dan grafik } \\
\text { untuk menemukan hubungan antara F dan x } \\
\text { secara kualitatif }\end{array}$ & $\begin{array}{l}\text { Inquiry Labs: } \\
\text { Peserta didik lebih lanjut melakukan percobaan } \\
\text { untuk mengamati hubungan antara massa } \\
\text { beban dengan pertambahan panjang pegas } \\
\text { (membuktikan hukum Hooke), menentukan } \\
\text { pengaruh penambahan massa beban terhadap } \\
\text { pertambahan panjang pegas yang disusun } \\
\text { secara seri dan parallel, dan menentukan } \\
\text { konstanta pegas gabungannya secara kuantitatif }\end{array}$ \\
\hline $\begin{array}{l}\text { Real-World Applications: } \\
\text { Menerapkan hukum Hooke dalam berbagai } \\
\text { situasi fisis yang terjadi dalam kehidupan } \\
\text { sehari-hari. }\end{array}$ & $\begin{array}{l}\text { Hypothetical Inquiry: } \\
\text { Peserta didik mengembangkan penjelasan atas } \\
\text { berbagai fenomena/permasalahan yang } \\
\text { berkaitan dengan hukum Hooke di kehidupan } \\
\text { sehari-hari }\end{array}$ \\
\hline
\end{tabular}

Dalam proses pembelajaran materi Elastisitas, model inkuiri dilaksanakan dalam $6 \mathrm{JP}$. Dengan menggunakan acuan Unit Pembelajaran Fisika Berbasis Inkuiri: Elastisitas yang telah dikembangkan oleh Tim Pengembang dari PPPPTK IPA Bandung yaitu Eddy Susianto, S. Pd., M. Si dan Suharto, S. Pd., M.T. Kompetensi dasar yang akan dicapai melalui pembelajaran ini adalah: 3.2: Menganalisis sifat elastisitas bahan dalam kehidupan sehari hari. 4.2: Melakukan percobaan tentang sifat elastisitas suatu bahan berikut presentasi hasil percobaan dan pemanfaatannya. Learning Sequence atau gambaran singkat mengenai kegiatan siswa disetiap level inquiry pada proses pembelajaran materi Elastisitas dapat dilihat dalam tabel berikut:

Tabel 2: Learning Sequence

\begin{tabular}{|c|c|}
\hline Kegiatan Guru & Kegiatan Siswa \\
\hline \multicolumn{2}{|c|}{ Level 1: Discovery Learning } \\
\hline $\begin{array}{l}\text { 1. Guru meminta siswa untuk mengungkapkan } \\
\text { pengalamannya terkait dengan bahan-bahan }\end{array}$ & $\begin{array}{l}\text { - Siswa menceritakan pen } \\
\text { yang diminta guru }\end{array}$ \\
\hline
\end{tabular}




\section{Kegiatan Guru}

\section{Kegiatan Siswa}

seperti karet, plastik, dan logam terutama sifat-sifatnya.

Selanjutnya guru menggali pengalaman siswa terkait pengggunaan dari bahan-bahan tersebut

2. Guru membagikan beberapa jenis pegas (minimal 3) dari yang lentur sampai yang kaku, beberapa beban, dan penggaris. Usahakan panjang mula-mula pegas sama. Guru mengarahkan siswa untuk mengamati pegas yang sudah dibagikan pada siswa

3. Guru memberikan pertanyaan sebagai berikut:

a. Adakah perbedaan dari pegas yang saya bagikan? Coba jelaskan!

b. Besaran-besaran IPA apa yang muncul ketika anda membedakan pegas-pegas tersebut?

c. Bagaimanakah cara anda dapat membedakan pegas-pegas tersebut?

d. Adakah nilai yang tetap dari perubahan panjang pegas yang kalian amati?

4. Guru memfasilitasi peserta didik untuk mendeskripsikan hasil pengamatannya

5. Guru menfasilitasi peserta didik untuk menjelaskan perbedaan dari pegas yang diamati peserta didik

- Peserta didik bergantian mengamati pegas yang diberikan oleh guru meliputi: Bahan, Panjang mula - mula, Perubahan panjang pegas ketika diberi beban.

- Peserta didik memberikan perlakuan pada 3 jenis pegas secara bergantian

- Peserta didik mengamati dan mencatat setiap perubahan yang terjadi pada masingmasing pegas, dan memberikan nama serta penjelasan dari tiap perubahan tersebut

- Siswa mencatat setiap perbedaan yang muncul pada 3 jenis pegas yang berbeda

- Siswa memberikan penjelasan kepada guru dan siswa yang lain hasil dari diskusi dan pengamatannya

6. Guru memfasilitasi peserta didik untuk menjelaskan besaran-besaran IPA yang muncul ketika peserta didik membedakan pegas-pegas tersebut. Guru dengan teknik prompting mengarahkan siswa untuk bisa menjelaskan secara lengkap besaran-besaran IPA yang muncul saat mereka melakukan pengamatan

7. Guru memfasilitasi peserta didik untuk menjelaskan bagaimana cara membedakan pegas-pegas yang diamati. Guru dengan teknik prompting mengarahkan siswa untuk bisa menjelaskan secara lengkap bagaimana peserta didik dapat membedakan pegaspegas yang diamati

peserta didik menjelaskan besaran-besaran IPA yang muncul ketika peserta didik membedakan pegas-pegas yang diamati

\section{Level 2: Interactive Demonstrations}

1. Guru menyiapkan pegas beserta statip serta beberapa massa beban. Guru menggantungkan ujung pegas pada statip. Selanjutnya guru bertanya pada siswa " coba perhatikan apa yang saya pegang ini! (sambil menunjukkan beberapa massa beban

peserta didik menjelaskan bagaimana cara membedakan pegas-

pegas yang diamati
- Peserta didik memperhatikan apa yang dikerjakan oleh guru. Peserta didik mengamati beberapa beban yang dipegang oleh guru.

- Peserta didik menyebutkan nominal nilai massa yang tertera pada beban. 


\begin{tabular}{|c|c|}
\hline Kegiatan Guru & Kegiatan Siswa \\
\hline $\begin{array}{l}\text { yang di massa tersebut tertera nilai } \\
\text { massanya). } \\
\text { Apa yang tertera di sini? Berapa nilainya? } \\
\text { (sambil menunjukkan nilai massa di beban). }\end{array}$ & \\
\hline $\begin{array}{l}\text { 2. Guru menyampaikan bahwa nilai massa } \\
\text { yang tertera pada beban berkaitan dengan } \\
\text { gaya luar yang bekerja pada pegas }\end{array}$ & $\begin{array}{l}\text { Peserta didik menyimak informasi yang } \\
\text { disampaikan oleh guru }\end{array}$ \\
\hline $\begin{array}{l}\text { 3. Guru menegaskan pada siswa bahwa gaya } \\
\text { luar yang bekerja pada pegas tidak lain } \\
\text { adalah gaya berat dari hubungan } \mathrm{F}=\mathrm{W}= \\
\mathrm{m.g}\end{array}$ & \\
\hline $\begin{array}{l}\text { 4. "Sekarang perhatikan pegas yang tergantung } \\
\text { ini! Ada yang bisa bantu saya, berapa } \\
\text { panjang pegas?" Guru mengacungkan } \\
\text { penggaris menawarkan pada peserta didik } \\
\text { untuk mengukur panjang pegas. "Jangan } \\
\text { lupa dicatat berapa panjangnya!" }\end{array}$ & $\begin{array}{l}\text { Peserta didik mengukur panjang mula-mula } \\
\text { pegas dari } \\
\text { penggaris yang ditawarkan oleh guru, dan } \\
\text { mencatat hasilnya. }\end{array}$ \\
\hline $\begin{array}{l}\text { 5. jika ujung pegas yang di bawah digantungkan } \\
\text { beban, apa yang terjadi pada pegas?" } \\
\text { selanjutnya guru menggantungkan } 1 \text { beban } \\
\text { pada ujung pegas. }\end{array}$ & $\begin{array}{l}\text { Peserta didik mengamati saat guru } \\
\text { menggantungkan beban } \\
\text { pada ujung pegas dan mengukur kembali } \\
\text { panjang pegasnya. Peserta didik } \\
\text { menjawab pertanyaan guru. }\end{array}$ \\
\hline $\begin{array}{l}\text { 6. "Selanjutnya jika semua beban ini } \\
\text { digantungkan semuanya pada ujung pegas } \\
\text { secara bertahap, apa yang terjadi pada pegas? } \\
\text { Guru menggantungkan satu persatu massa } \\
\text { beban pada ujung pegas. "Silahkan catat } \\
\text { perubahannya, yang terjadi pada pegas dan } \\
\text { jumlah beban yang digantungkan!" (catt: } \\
\text { usahakan jumlah beban yang digantungkan } \\
\text { sampai mencapai keadaan plastis untuk } \\
\text { pegasnya) }\end{array}$ & $\begin{array}{l}\text { Siswa mengamati dan mencatat perubahan } \\
\text { panjang pegas saat } \\
\text { guru memberikan nilai beban yang berbeda- } \\
\text { beda. }\end{array}$ \\
\hline $\begin{array}{l}\text { 7. “Nah dari apa yang sudah kita amati } \\
\text { bersama, adakah dari kalian yang bisa } \\
\text { menyimpulkan?” Dengan teknik prompting } \\
\text { guru menuntun peserta didik untuk dapat } \\
\text { menyimpulkan secara benar bahwa ada } \\
\text { hubungan antara gaya luar, gaya pulih } \\
\text { dengan pertambahan panjang pada pegas. }\end{array}$ & $\begin{array}{l}\text { - } \begin{array}{l}\text { Peserta didik berdiskusi untuk menjawab } \\
\text { pertanyaan guru berdasarkan hasil } \\
\text { pengamatan. }\end{array} \\
\text { Peserta didik memberikan } \\
\text { penjelasan/mempresentasikan jawaban } \\
\text { pertanyaan guru dari hasil diskusi kelompok. } \\
\text { - Peserta didik menyimpulkan hubungan antara } \\
\text { gaya luar, gaya pulih dengan pertambahan } \\
\text { panjang pada pegas. }\end{array}$ \\
\hline \multicolumn{2}{|c|}{ Level 3: Inquiry Lessons } \\
\hline $\begin{array}{l}\text { 1. Guru mereviu kembali apa yang sudah } \\
\text { dilakukan siswa dan diketahui siswa. "dari } \\
\text { apa yang sudah kalian amati dan kerjakan, } \\
\text { bisa tolong sebutkan kembali besaran- } \\
\text { besaran IPA apa yang muncul saat pegas } \\
\text { sebelum dan sesudah diberikan beban?" }\end{array}$ & $\begin{array}{l}\text { Siswa bergantian menjawab pertanyaan dari } \\
\text { guru. (Jawaban yang diharapan muncul adalah } \\
\text { pertambahan panjang pegas, massa beban, posisi } \\
\text { kesetimbangan, perpindahan dari posisi } \\
\text { setimbang, rapatan dan regangan pegas). }\end{array}$ \\
\hline 2. Coba lihat kembali catatan kalian, pada & Peserta didik melihat kembali catatan saat \\
\hline
\end{tabular}




\section{Kegiatan Guru}

pengamatan pada demostrasi yang sudah saya lakukan sebelumnya korelasi apa yang terjadi antara gaya luar dengan posisi pegas? Guru menuntun siswa agar menemukan hubungan bahwa semakin bertambah besar gaya luar, pertambahan panjang pegas semakin besar pula

3. Berdasarkan data yang kalian catat pada saat demonstrasi, pindahkan data tersebut dalam bentuk grafik berdasarkan variabelnya! Guru membimbing siswa untuk mengkonversi data menjadi grafik hubungan antara gaya luar tehadap pertambahan panjang pegas. $* * * *$

4. "Perhatikan pola grafik yang sudah kalian buat, bagaimana kecenderungannya? Dan apa maknanya!" guru membimbing peserta didik agar bisa menterjemahkan grafik hubungan antara $\mathrm{F}$ terhadap $\Delta \mathrm{x}$ dan menemukan konsep tetapan pegas. $* * * * * *$

\section{Kegiatan Siswa}

demonstrasi, berdiskusi dengan teman sebangku/sekelompok dan mencoba menjawab pertanyaan guru.
Peserta didik berlatih mengkonversi data hasil pengamatan yang berupa tabel menjadi grafik hubungan antara $\mathrm{F}$ terhadap

$\Delta \mathrm{x}$.
- Siswa menganalisis pola grafik untuk menemukan nilai tetapan pegas.

- Siswa mempresentasikan hasil diskusi kelompoknya terkait nilai tetapan pegas. (Harapannya Peserta didik dapat menyatakan bahwa ada keteraturan antara pertambahan panjang dengan gaya luarnya yang ditandai dengan pola grafik yang mendekati garis lurus yang condong ke kanan.)

5. Guru memberikan pertanyaan sambil menunjukkan 2 pegas di setiap tangannya. "Apakah setiap pegas mempunyai nilai tetapan yang sama?"

\section{Level 4: Inquiry Labs}

1. Guru menugaskan siswa untuk membentuk kelompok kemudian menyiapkan masingmasing 3 buah pegas yang berbeda kelenturannya, sepaket beban, statip dan meminta siswa menyiapkan penggarisnya.

2. Guru menugaskan pada siswa untuk merancang dan melakukan percobaan untuk menentukan nilai tetapan masing-masing pegas yang ada pada tiap kelompok. "Berdasarkan pengalaman kalian saat mengamati demonstrasi dan menterjemahkan grafik, silahkan rancang dan lakukan eksperimen untuk menentukan nilai tetapan pegas yang ada pada tiap kelompok!"******

3. Setelah semua kelompok menyelesaikan eksperimennya, guru menugaskan tiap kelompok mempresentasikan hasil percobaannya. Guru menfasilitasi peserta didik untuk menyajikan data hasil percobaan, analisis data dan kesimpulan hasil percobaan.

4. Setelah semua kelompok presentasi guru
Siswa membentuk kelompok dan mengambil peralatan yang disediakan oleh guru.

- Siswa berdiskusi dengan kelompoknya untuk merancang desain eksperimen untuk menentukan nilai tetapan pegas.

- Tiap kelompok melaksanakan eksperimen berdasarkan desain yang telah dirancang.

Tiap kelompok mempresentasikan hasil eksperimennya secara bergantian. 


\begin{tabular}{|c|c|}
\hline Kegiatan Guru & Kegiatan Siswa \\
\hline $\begin{array}{l}\text { memberikan pertanyaan terkait nilai tetapan } \\
\text { pegas terdapat kelenturan pegas. } \\
\text { "Bandingkan hasil percobaan kelompok anda } \\
\text { dengan kelompok yang lain, adakah } \\
\text { hubungan antara nilai tetapan pegas terhadap } \\
\text { kelenturan pegas? Waktunya } 10 \text { menit, } \\
\text { setelah itu secara acak saya minta perwakilan } \\
\text { kelompok untuk menjelaskannya!" }\end{array}$ & $\begin{array}{l}\text { mengamati dan membandingkan data dan } \\
\text { hasil percobaannya dengan kelompok yang } \\
\text { lain. (Data yang dibandingkan adalah } \\
\text { hubungan antara } \mathrm{F} \text { dengan } \Delta \mathrm{X} \text { untuk tiap } \\
\text { pegas yang berbeda) } \\
\text { - Siswa menverikasi hipotesis di } \\
\text { kelompoknya dengan hasil pengolahan data } \\
\text { di kelompok yang lain. } \\
\text { Siswa berdiskusi dengan kelompoknya dan } \\
\text { menyimpulkan hubungan antara tetapan } \\
\text { dengan tingkat kelenturan suatu pegas. }\end{array}$ \\
\hline $\begin{array}{l}\text { 5. Guru meminta peserta didik untuk } \\
\text { menuliskan hubungan matematis antara gaya } \\
\text { pulih, tetapan pegas dan pertambahan } \\
\text { panjang. }\end{array}$ & $\begin{array}{l}\text { Peserta didik menuliskan hubungan } \\
\text { matematis antara gaya pulih, tetapan pegas } \\
\text { dan pertambahan panjang. }\end{array}$ \\
\hline $\begin{array}{l}\text { 6. Guru menguatkan konsep tetapan pegas dan } \\
\text { hubungan antara nilai tetapan dengan tingkat } \\
\text { kelenturan suatu pegas. }\end{array}$ & $\begin{array}{l}\text { Siswa menyimak dan menyampaikan pertanyaan } \\
\text { bila ada yang belum mengerti dari penjelasan } \\
\text { guru. }\end{array}$ \\
\hline $\begin{array}{l}\text { 7. Guru menugaskan siswa untuk } \\
\text { mengumpulkan pegas yang sama nilai } \\
\text { tetapannya berdasarkan hasil ekperimen. } \\
\text { Selanjutnya guru membagikan LK untuk } \\
\text { melaksanakan eksperimen seri dan paralel. }\end{array}$ & $\begin{array}{l}\text { Peserta didik mengumpulkan pegas yang } \\
\text { nilai tetapannya sama dan melaksanakan } \\
\text { eksperimen sesuai LK yang dibagikan guru. } \\
\text { Peserta didik meyusun pegas secara seri, } \\
\text { dengan cara yang sama pada eksperimen } \\
\text { sebelumnya, peserta didik menentukan nilai } \\
\text { tetapan pegas gabungan. } \\
\text { Peserta didik meyusun pegas secara paralel. } \\
\text { Dengan cara yang sama pada eksperimen } \\
\text { sebelumnya, peserta didik menentukan nilai } \\
\text { tetapan pegas gabungan. } \\
\text { Peserta didik menyimpulkan keterkaitan } \\
\text { antara nilai tetapan pegas gabungan dengan } \\
\text { nilai tetapan pegas awal sebelum } \\
\text { dirangkai/disusun. }\end{array}$ \\
\hline $\begin{array}{l}\text { 8. Guru mengarahkan siswa untuk } \\
\text { mempresentasikan hasil eksperimennya dan } \\
\text { menuliskan persamaan matematis dari } 2 \\
\text { ekperimen tersebut (seri dan paralel). }\end{array}$ & $\begin{array}{l}\text { Peserta didik mempresentasikan hasil } \\
\text { eksperimennya dan menuliskan persamaan } \\
\text { matematis dari } 2 \text { ekperimen tersebut (seri dan } \\
\text { paralel). }\end{array}$ \\
\hline \multicolumn{2}{|c|}{ Level 5: Real-World Applications } \\
\hline $\begin{array}{l}\text { 1. Guru menampilkan gambar dan } \\
\text { menyampaikan pertanyaan pada siswa. } \\
\text { Soal pertama: }\end{array}$ & 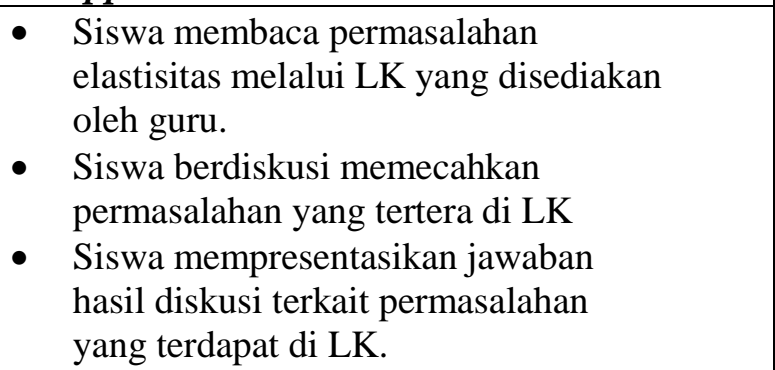 \\
\hline
\end{tabular}




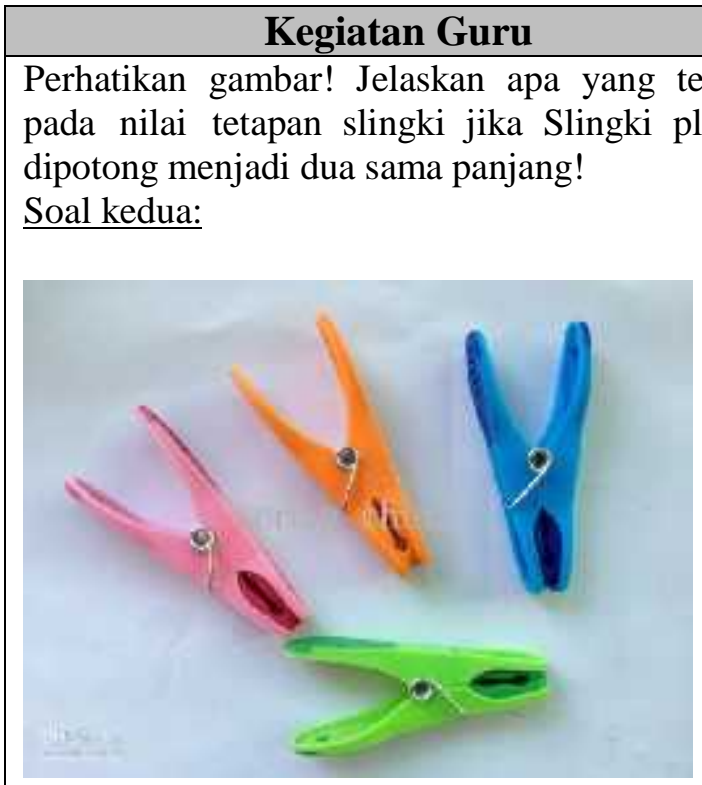

Perhatikan gambar! jika per pada jepitan jemuran dipotong menjadi 2 sama besar, dan dibentuk seperti semula, jelaskan apa yang terjadi pada jepitan jemuran tersebut!

Soal ketiga:

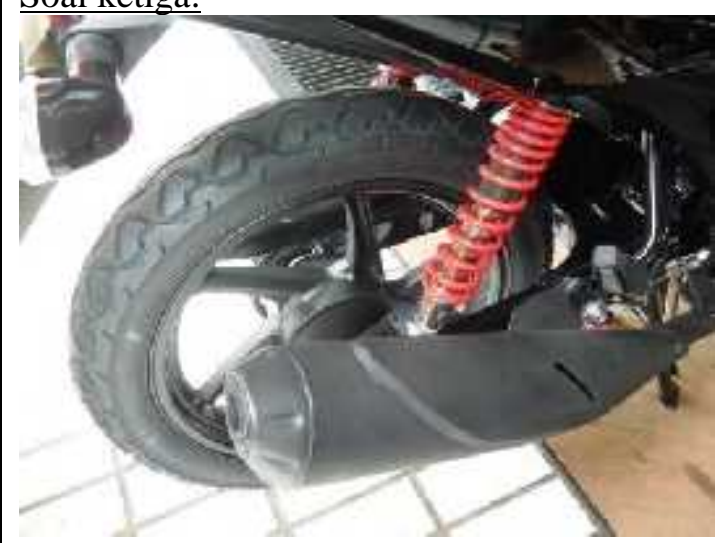

"Perhatikan gambar, jika pengendara motor ingin membuat motornya kuat menahan beban berat dan tetap mendapatkan kenyamanan dari redaman shockbreaker. Jelaskan shockbreaker seperti apa yang harus dIPAsang di motor tersebut!

\section{Level 6: Hypothetical Inquiry}

2. Guru membagikan dan menayangkan 2 soal Kegiatan di kelas: dengan gambar sebagai tugas project pada peserta didik dan dikumpulkan satu minggu setelah tugas diberikan. Tugas bersifat kelompok.

Soal Pertama:

Perhatikan gambar, Gambar di kiri adalah motor dengan shock breaker ganda. Bila pemilik motor ingin mengganti dengan shock

Peserta didik berdiskusi secara berkelompok dan menuliskan hipotesisnya berdasarkan pengalaman serta pengetahuan yang dimiliki oleh peserta didik.

Kegiatan diluar kelas. 


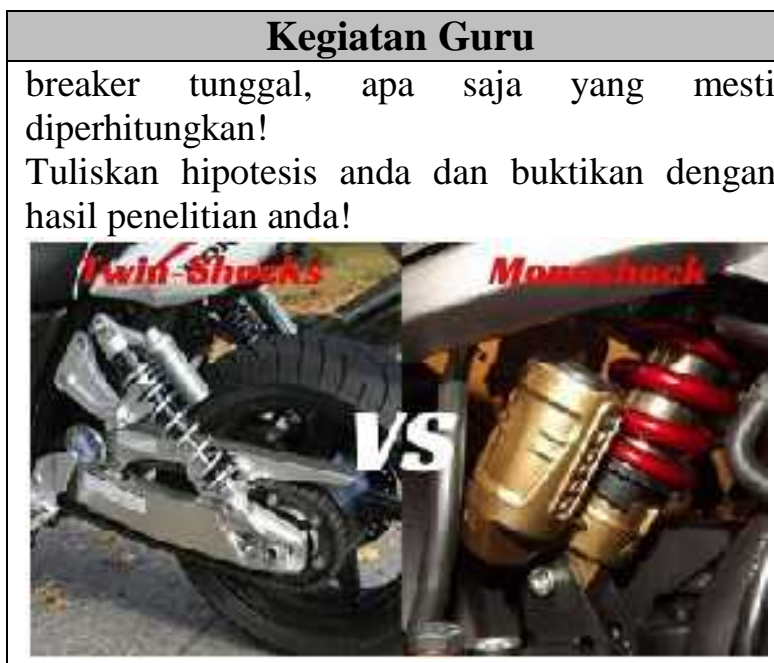

Kesimpulan apakah yang anda dapatkan terkait hukum Hooke

\section{Soal Kedua:}

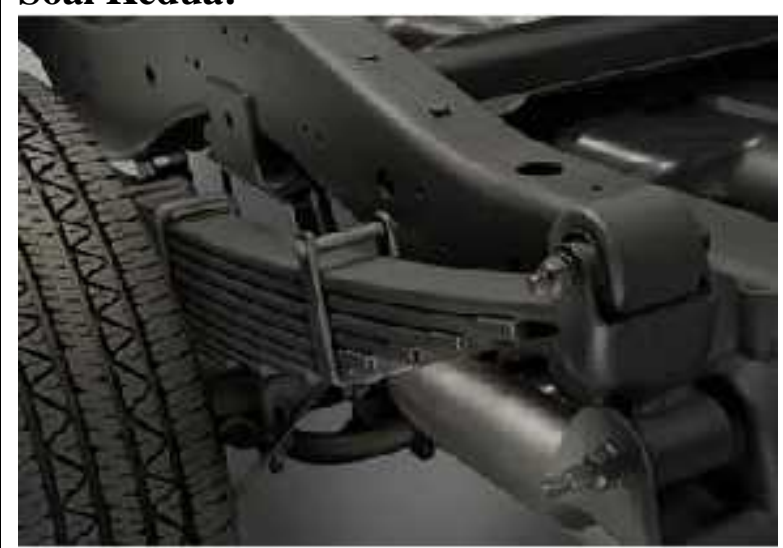

Bila pengemudi truk ingin dapat mengangkut barang dengan beban yang lebih berat. Jelaskan apa yang harus dilakukan pengemudi truk pada shock breakernya! Tuliskan hipotesis anda dan buktikan dengan hasil penelitian anda!

\section{Kegiatan Siswa}

Peserta didik mengadakan penelitian untuk menjawab hipotesisnya dengan:

3. Mencari referensi melalui internet terkait masalah yang ada pada soal.

4. Bertemu langsung dengan narasumber/praktisi yang terkait permasalahan pada soal. Peserta didik dapat mengunjungi bengkel motor dan bengkel mobil/truk.

Setelah batas waktu yang ditentukan berakhir, peserta didik secara berkelompok satu hari sebelum presentasi,menyerahkan hasil penelitiannya kepada guru melalui email.

Secara berkelompok peserta didik mempresentasikan hasil penelitiannya di depan kelas

Pembelajaran topik elastisitas dilaksanakan dalam 3 pertemuan. Masing-masing pertemuan selama 2 jam pelajaran (@45 menit). Uraian mengenai pelaksanaan proses pembelajaran secara singkat sebagai berikut:

- Pertemuan Pertama: 2 x 45 menit:

$>$ Pada pertemuan pertama, LOI yang dapat diselesaikan ada 2 yaitu; Discovery Learning (DL) dan Interactive Demonstration (ID). Sebelum pelaksanaan pembelajaran, siswa diberikan pre test dan diakhir pelaksanaan pembelajaran siswa diberikan post test;

$>$ Dalam level Discovery Learning (DL) terdapat keterampilan mengelompokkan, mengurutkan, menggeneralisasi, menyimpulkan, mengkonseptualkan, mengkontekstualkan, dan mempermasalahkan. Peserta didik diberi beberapa jenis pegas untuk diamati, guru mengarahkan perhatian dan tindakan siswa pada konsep-konsep berikut: tetapan pegas, gaya luar, pertambahan panjang, dan gaya pulih; 
Keterampilan intelektual pada level Interactive Demonstration (ID) adalah mengestimasi, memprediksi, menjelaskan, berfikir kondisional, dan menilai konsekuensi hasil pengamatan. Pada tahap ini, Guru menunjukkan pengaruh perubahan gaya terhadap pertambahan panjang pegas. Peserta didik difokuskan untuk dapat memprediksi hubungan antara gaya luar, gaya pulih dan pertambahan panjang pegas .

$>$ Hambatan yang terjadi pada pertemuan pertama ini adalah koneksi internet ketika membuka applikasi Pemanfaatan Elastisitas web terkadang tidak stabil, hal ini dapat diselesaikan dengan memberikan alternatif menggunakan Video Pembelajaran.

\section{- Pertemuan Kedua: 2 x 45 menit:}

$>$ Di pertemuan ke dua LOI yang dilaksanakan yaitu Inquiry lesson (IL) dan Inquiry Laboratory (IL), Guru menugaskan siswa untuk membentuk kelompok kemudian menyiapkan masing-masing 3 buah pegas yang berbeda kelenturannya, sepaket beban, statip dan meminta siswa menyiapkan penggarisnya; Peserta didik melakukan percobaan untuk mengamati hubungan antara massa beban dengan pertambahan panjang pegas melalui pengumpulan data dan grafik untuk menemukan hubungan antara $\mathrm{F}$ dan $\mathrm{x}$ secara kualitatif;

$>$ Guru menugaskan pada siswa untuk merancang dan melakukan percobaan untuk menentukan nilai tetapan masing-masing pegas yang ada pada tiap kelompok. "Berdasarkan pengalaman kalian saat mengamati demonstrasi dan menterjemahkan grafik, silahkan rancang dan lakukan eksperimen untuk menentukan nilai tetapan pegas yang ada pada tiap kelompok. Siswa berdiskusi dengan kelompoknya untuk merancang desain eksperimen untuk menentukan nilai tetapan pegas, Tiap kelompok melaksanakan eksperimen berdasarkan desain yang telah dirancang;

$>$ Masalah yang terjadi pada pertemuan dua ini adalah tidak dapat terselesaikannya level IL. Dalam 90 menit hanya dapat terlaksana pembelajaran Mengukur nilai/besar pertambahan panjang pegas saat dikenai gaya, hal ini disebabkan karena abstraknya isi materi tersebut dan waktunya terbatas. Pemecahan masalah seperti menyimpulkan hasil pengamatan dan menganalisis Grafik hubungan antara $\mathrm{F}$ dan $\Delta \mathrm{X}$ untuk menentukan konstanta pegas dilakukan dengan cara memberi tugas pada akhir pertemuan dua dan melanjutkan pembelajaran di pertemuan ke tiga;

- Pertemuan Ketiga: 2 x 45 menit:

$>$ Pada pertemuan ketiga proses pembelajaran yang dilakukan adalah menyelesaikan level IL pada pertemuan sebelumnya, yakni menugaskan masing - masing siswa secara berkelompok untuk mempresentasi hasil pengamatannya;

$>$ Guru menampilkan gambar dan menyampaikan pertanyaan pada siswa, Siswa membaca permasalahan elastisitas melalui LK yang disediakan oleh guru, Siswa berdiskusi memecahkan permasalahan yang tertera di LK Siswa mempresentasikan jawaban hasil diskusi terkait permasalahan yang terdapat di LK

$>$ Guru membagikan dan menayangkan 2 soal dengan gambar sebagai tugas project pada peserta didik dan dikumpulkan satu minggu setelah tugas diberikan. Tugas bersifat kelompok. Kegiatan di Sekolah: Peserta didik berdiskusi secara berkelompok dan menuliskan hipotesisnya berdasarkan pengalaman serta 
pengetahuan yang dimiliki oleh peserta didik. Kegiatan di Luar Sekolah: Peserta didik mengadakan penelitian untuk menjawab hipotesisnya.

$>$ Pertemuan ketiga ini dilaksanakan LOI Hypothetical Inquiry (HI). Keterampilan yang dilatihkan pada level ini siswa berhipotesis tentang kemungkinan adanya Fenomena/permasalahan yang berkaitan dengan Hukum Hooke di kehidupan sehari - hari;

$>$ Pada pertemuan ketiga tidak ada hambatan yang berarti. Setelah pembelajaran selesai, dilaksanakan tes akhir untuk mengetahui lebih jauh materi Elastisitas dan Hukum Hooke;

Dari tes yang dilakukan didapat hasil belajar yang digunakan untuk megukur tingkat penguasaan dan pemahaman siswa tentang materi Elastisitas dan Hukum Hooke. Hasil belajar siswa XI IPA SMA Negeri 2 Donggo Tahun Pelajaran 2019/2020 menunjukkan 100\% tuntas KKM.

\section{Kesimpulan}

Kesimpulan yang diperoleh dari hasil penelitian ini bahwa proses pembelajaran inkuiri pada materi Elastisitas dan Hukum Hooke dengan menggunakan unit pembelajaran Fisika Hukum Hooke P4TK IPA pada siswa kelas XI IPA SMA Negeri 2 Donggo Kabupaten Bima dapat dilaksanakan dengan baik dan hasil belajar siswa $100 \%$ tuntas.

\section{Saran}

Adapun saran yang dapat disampaikan berdasarkan hasil penelitian ini adalah untuk memperkaya pengalaman proses belajar mengajar yang memenuhi tuntutan kurikulum yang berlaku dan tantangan abad 21, perlu dikembangkannya unit pembelajaran berbasis inkuiri dengan Materi Fisika di SMA yang lain.

\section{Daftar Pustaka}

Anisah, N. (2020). Upaya Peningkatan Minat Baca dan Pengetahuan Siswa Melalui Model Pembelajaran Inkuiri di MTs. Miftahul Huda Jleper Demak Jawa Tengah. Jurnal Paedagogy, 7(4), 408-415. doi:https://doi.org/10.33394/jp.v7i4.2947

Joyce, B \& Weil, M. With Calhoun, E. (2000). Models of Teaching. 6th edition. Boston: Allyn and Bacon.

Nahak, R., \& Bulu, V. (2020). Efektivitas Model Pembelajaran Inkuiri Terbimbing Berbantu Lembar Kerja Siswa Berbasis Saintifik Terhadap Hasil Belajar Siswa. Jurnal Kependidikan: Jurnal Hasil Penelitian dan Kajian Kepustakaan di Bidang Pendidikan, Pengajaran dan Pembelajaran, 6(2), 230-237. doi:https://doi.org/10.33394/jk.v6i2.2369

Nurkhasanah, S. (2019). Penerapan Model Pembelajaran Inkuiri untuk Meningkatan Aktifitas Belajar Siswa pada Mata Pelajaran Ilmu Pengetahuan Alam Kelas IX.A SMP Negeri 1 Gangga. Jurnal Kependidikan: Jurnal Hasil Penelitian dan Kajian Kepustakaan di Bidang Pendidikan, Pengajaran dan Pembelajaran, 5(1), 47-53. doi:https://doi.org/10.33394/jk.v5i1.1393

Rutaman, Nuryani. (2005). Perkembangan Penelitian Pembelajaran Berbasis Inkuiri Dalam Pendidikan Sains. Makalah Presentasi. Bandung: Tidak diterbitkan

Seprianingsih, D. (2017). Pengembangan Perangkat Pembelajaran Biologi Berbasis Inkuiri Terbimbing dalam Meningkatkan Penguasaan Konsep Biologi Siswa. Jurnal Kependidikan: Jurnal Hasil Penelitian dan Kajian Kepustakaan di Bidang 
Pendidikan, Pengajaran dan Pembelajaran, doi:https://doi.org/10.33394/jk.v3i1.467

Soekarman. (2017). Strategi Pembelajaran Inovatif Sains di Abad ke - 21. Surabaya: Pustaka Media Guru

Susianto, Eddy. Dkk. (2018). Unit Pembelajaran Fisika Hukum Hooke. Bandung: PPPPTK IPA Bandung

Wenning, C.J. (2010). Levels of inquiry: Using inquiry spectrum learning sequences to teach science. Journal of Physics Teacher Education Online, 5(4), 1119. 